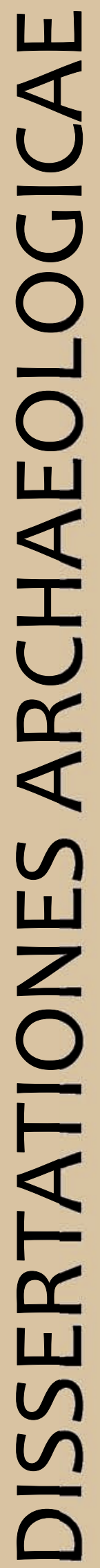

ex Instituto Archaeologico Universitatis de Rolando Eötvös nominatae

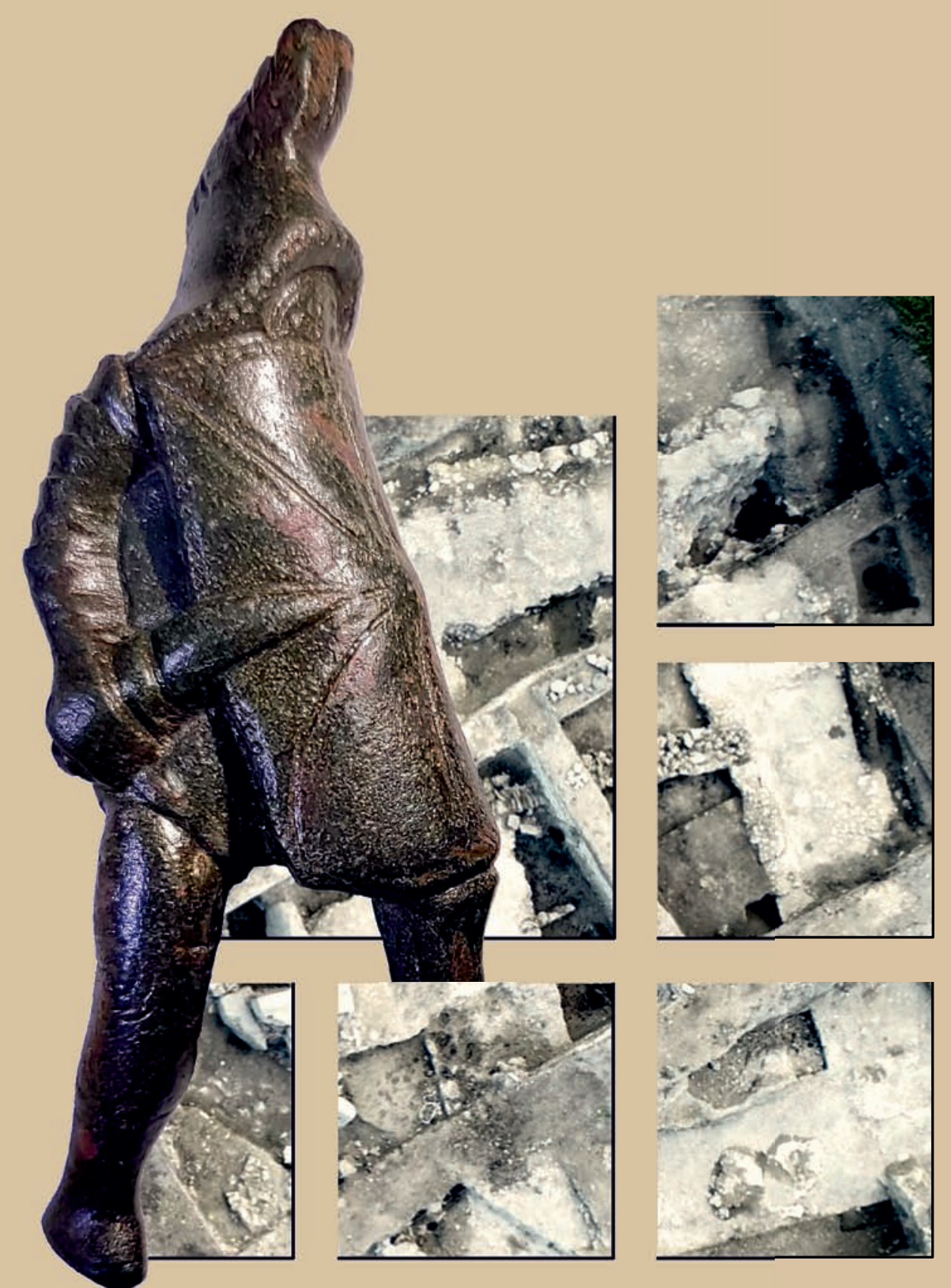

$$
\text { Ser. 3. No. 7. } 2019
$$




\section{Dissertationes Archaeologicae ex Instituto Archaeologico}

Universitatis de Rolando Eötvös nominatae Ser. 3. No. 7.

Budapest 2019 
Dissertationes Archaeologicae ex Instituto Archaeologico Universitatis de Rolando Eötvös nominatae

Ser. 3. No. 7.

Editor-in-chief:

DÁvid BARTUS

Editorial board:

LÁsZló BARTOSIEWICZ

LÁSZLÓ BORHY

ZOLTÁN CZAJLIK

IsTVÁN FELD

GÁBOR KALLA

PÁL RACZKY

MikLÓs SzABÓ

TivadAR VidA

Technical editor:

GÁBOR VÁCZI

Proofreading:

SZILVIA BARTUS-SZÖLLősI

ZsóFIA KondÉ

Aviable online at http://dissarch.elte.hu

Contact: dissarch@btk.elte.hu

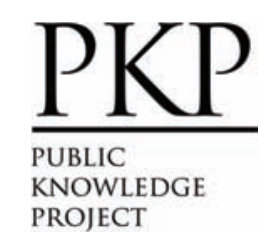

๑ ELTE Eötvös Loránd University, Institute of Archaeological Sciences

Layout and cover design: Gábor Váczi

Budapest 2019 


\section{CONTENTs}

\section{ARticles}

János Gábor TARBAY

The Casting Mould and the Wetland Find - New Data on the Late Bronze Age

Peschiera Daggers

Máté MeRvel

Late Bronze Age stamp-seals with negative impressions of seeds from Eastern Hungary

János Gábor TARBAY

Melted Swords and Broken Metal Vessels - A Late Bronze Age Assemblage

from Tatabánya-Bánhida and the Selection of Melted Bronzes

Ágnes ScHNEIDER

Multivariate Statistical Analysis of Archaeological Contexts: the case study

of the Early La Tène Cemetery of Szentlörinc, Hungary

Csilla SÁRÓ - Gábor LASSÁNYI

Bow-tie shaped fibulae from the cemetery of Budapest/Aquincum-Graphisoft Park

Dávid BARTus

Roman bronze gladiators - A new figurine of a murmillo from Brigetio

Kata DÉvAI

Re-Used Glass Fragments from Intercisa

Bence Simon

Rural Society, Agriculture and Settlement Territory in the Roman, Medieval and Modern Period Pilis Landscape

Rita RAKONCZAY

„Habaner“ Ofenkacheln auf der Burg Čabrad”

\section{FIELD REPORT}

Bence Simon - Anita Benes - Szilvia Joháczi - Ferenc BARnA

New excavation of the Roman Age settlement at Budapest dist. XVII, Péceli út (15127) site 


\section{Thesis Abstracts}

Kata SzILÁGYi

Die Silexproduktion im Kontext der Südosttransdanubischen Gruppe

der spätneolithischen Lengyel-Kultur

Norbert FARAGÓ

Complex, household-based analysis of the stone tools of Polgár-Csőszhalom

János Gábor TARBAY

Type Gyermely Hoards and Their Dating - A Supplemented Thesis Abstract

Zoltán Havas

The brick architecture of the governor's palace in Aquincum

Szabina Merva

'...circa Danubium...' from the Late Avar Age until the Early Árpádian Age-

$8^{\text {th }}-11^{\text {th }}$-Century Settlements in the Region of the Central Part of the Hungarian

Little Plain and the Danube Bend

Szabolcs Balázs NAGY

Noble Residences in the $15^{\text {th }}$ century Hungarian Kingdom - The Castles of Várpalota,

Ujlak and Kisnána in the Light of Architectural Prestige Representation

Ágnes KollátH

Tipology and Chronology of the early modern pottery in Buda 


\title{
Tipology and Chronology \\ of the early modern pottery in Buda
}

\author{
ÁgNes Kolláth \\ Institute of Archaeology \\ Research Centre for the Humanities \\ kollathagnes@gmail.com
}

\begin{abstract}
Abstract of PhD thesis submitted in 2019 to the Archaeology Doctoral Programme, Doctoral School of History, Eötvös Loránd University Budapest, under the supervision of István Feld.
\end{abstract}

\section{Aims of the dissertation}

One of the largest and most complex find groups in archaeology is pottery. This is especially true for Early Modern Period contexts (datable roughly between the $16^{\text {th }}$ and $18^{\text {th }}$ centuries) such as the ones this dissertation deals with. Namely, the mass production and trade of ceramics began in this era. Furthermore, Hungary lay on the borderlands of the Ottoman and Habsburg Empires, which resulted in vessel types rooted in different cultural backgrounds. This is exponentially true in the case of an economic and administrative centre like Buda. For that reason, the former capital of the Hungarian Kingdom offers an exceptionally good, but also difficult terrain for pottery research.

The dissertation contains the evaluation of thirteen find complexes from the excavations of a prominent location in the Buda Castle, the Szent György tér (Saint George Square), carried out by the Budapest History Museum in the 1980's and 1990's.

The main priority was to set up the typology and chronology of these finds. Further key objectives were to determine find horizons that are typical for shorter periods of time (50-70 years) and to map the connections of Buda and the town district on the territory of the modern Szent György tér through time and space. The issues of local pottery production and the data regarding the early modern period history and topography of the area have also been presented.

\section{The location and the evaluated objects}

The find complexes have come to light on the southern, narrowing part of the Buda Castle Hill, on the Szent György tér and in the surrounding buildings. The settlement and research history of the site are both rather complex (Fig. 1). ${ }^{1}$

Although there had been significant settlements in this location during the Copper and Bronze Ages, the hill was mostly deserted afterwards until the $13^{\text {th }}$ century AD. It is much debated whether the first settlement was formed here before the Mongolian Invasion (1241-1242),

1 See Fekete 1944; Feld 1999; KÁrpáti 2003; Magyar 2003; Nyékhelyi 2003; VÉGH 2003; VÉGH 2006; Hegyi 2007; VÉGH 2008; SUDÁR 2014; SIMON 2017 with further literature. 
or in the aftermath of this catastrophe, when Béla IV resettled the inhabitants of Pest (located on the other side of the Danube) to the hill. Some remains have come to light on the northern part of the area in question that precede the founding of the planned city and the erection of its first fortifications, but these were not datable more precisely within the $13^{\text {th }}$ century.

It is notable, that this territory has never been such an open space during the Middle Ages and the Early Modern Period, as it is today. Its plot-system was established trailing two northsouth directed streets (today Szent György utca and Színház utca) that lead southwards from two city gates in the direction of the Royal Palace. The plots along the roads were built in by houses, while the city walls stood as the eastern and western boundaries of the district. The southern border had been pulled back northwards multiple times, as the Royal Palace took up more and more space.

The growing importance of Buda as a royal seat has also played a crucial role in the development of the area. In its early phase, the north-western part of the Szent György utca was populated by Jews, whose synagogue has been identified. The other inhabitants were also mainly commoners. The earliest Christian ecclesiastic institution had been the Franciscan Monastery of Szent János (Saint John) since the middle of the $13^{\text {th }}$ century, on the eastern side of the modern square, now located under the Sándor Palace and the new Prime Minister's Residence.

This convent had kept its significance along the centuries, while other parts of the district changed considerably by the time of the Ottoman conquest. The Church of Saint Sigismund (Szent Zsigmond-templom) alias the Lesser Church of the Virgin Mary has been built between the two streets, facing the northern outer wall of the Royal Palace. The Jews have already had to move to another part of the town in the $14^{\text {th }}$ century, and most of the Christian craftsmen had also been replaced by nobility, who wanted to have a residence in the vicinity of the court. Although Buda had suffered through more than one sieges during the tumultuous first dec-

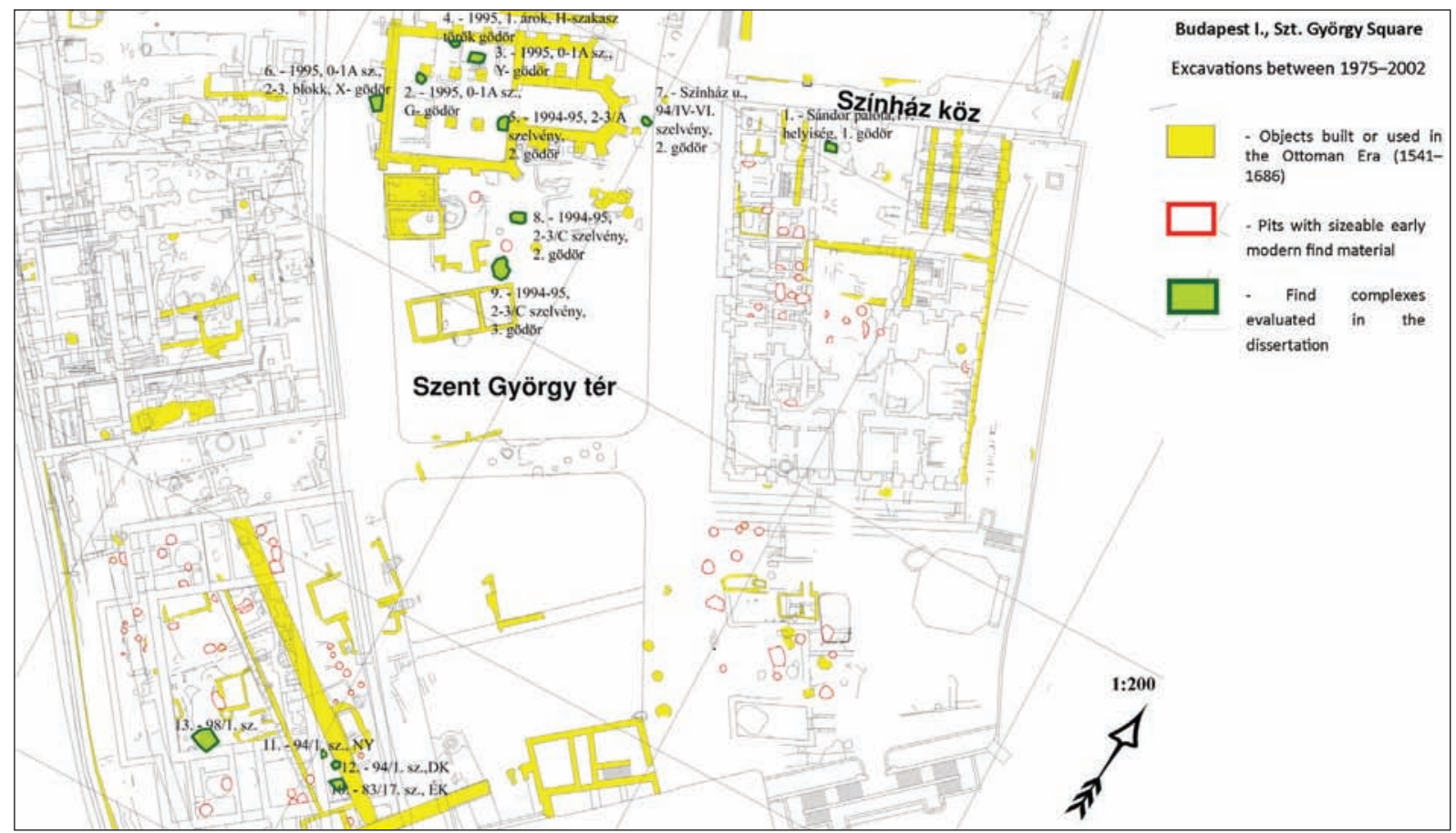

Fig. 1. The evaluated archaeological features and their location within Budapest I, Szent György Square (Map by Zs. Viemann; A. Tóth; Á. Kolláth). 
ades of the $16^{\text {th }}$ century which caused damages in this neighbourhood as well, the armies of the Sultan entering the city in 1541 found a prospering district here, adorned by Renaissance palaces.

We have surprisingly few written sources about the area from the time of the Ottoman rule. For example, it is completely absent from the published $16^{\text {th }}$ century tax records (defters). The most important building had been the Pasha's Palace since the end of the 1500's, beginning of the 1600's, built adjacent to the former Szent János Franciscan Convent. The governor had moved his seat to this better protected location after the sieges during the so-called Long War (1593-1606) from the Víziváros (Water Town) suburb.

The church of the convent had been transformed to his private $d s a m i$, and there most probably have been changes on the surrounding plots as well. For example, Evliya Çelebi mentioned the house of the Pasha's deputy, the kethuda, on the opposite side of the street.

The sieges of 1684 and 1686 had also done considerable damage to this district, but the surveys taken after the recapture recorded that the churches of Szent János and Szent Zsigmond and a few civilian houses survived. The neighbourhood was mainly in use by the military and the church on the turn of the $17^{\text {th }}-18^{\text {th }}$ centuries. The Carmelites have built their convent on the plot of the Pasha's Palace and the Szent János Church, and numerous barracks have been built on the area for the garrison. The square has also got its name in this period, due to an incorrect re-identification. The Armoury (Zeughaus) has been standing on the southern border of the district until the beginning of the $20^{\text {th }}$ century, while the waterworks in the northern part have played an important role in the city's life until the $19^{\text {th }}$ century. The Church of Szent Zsigmond was demolished in the 1770's.

The square's profile has changed again after the reconstruction of the Royal Palace, as the aristocrats have returned to build their residences. Later, by the beginning of the $20^{\text {th }}$ century, the area has become a government district. The monumental buildings of ministries and other administrative institutions have suffered damages in World War II. Although most of them could have possibly been saved, some have been demolished, while others stood unrepaired and mostly abandoned for decades.

Numerous plans have been made for the reviving of the area, which has required preventive archaeological work on an ever expanding scale since the 1970's. The excavations and other tasks have been carried out more or less continuously on different parts of the square until this day. The find complexes evaluated in this dissertation were found in the 1990's.

As more than a hundred similar "Turkish pits" have been excavated during the course of several years, the most suitable archaeological features have been chosen with the help of the excavations' supervisors. The main concerns were the datability and/or the 'promising' find material of these archaeological features, but the lack of space and capacity in the museum's depository has had to be taken in consideration as well. Finally, the finds of thirteen archaeological features have been processed, which means more than 10500 pottery shards, belonging to approximately 5000 vessels.

Only the so-called Pit 1 (the features have been renumbered for easier handling) was a completely closed complex. It was located on the eastern side of the square, and came to light during the excavations of the Sándor Palace (today the Residence of the President of the 
Republic), on the former courtyard of the Franciscan Convent. It was of medieval origin and was probably created as a storage pit. According to Eszter Kovács - who has evaluated the Ottoman period building activities of the convent - the pit had been filled up during the reconstruction works connected to the building of the Pasha's Palace and the renovation of the Szent János Church as its dsami. The courtyard was levelled and paved at this time, this stone pavement has also been excavated and its repairs could be observed as well. ${ }^{2}$

Pits 2-9 have come to light on the middle of the square. The archaeological context was especially unfavourable in this zone, as the terrain had been somewhat elevated here until vast levelling works took place in the $19^{\text {th }}$ century, destroying all layers above the bedrock. As a result, only substructures, cellars and pits dug in the marl could be observed. ${ }^{3}$

Pits 2-5 were located inside the Church of Szent Zsigmond, while Pit 6 had been dug by the outer side of the building's western wall and Pit 7 was found on the eastern side, a few meters from the sanctuary, opposite the Pasha's Palace in the modern Színház utca. A silver denarius of Rudolf I (1576-1612, Rudolf II as the Emperor of the Holy Roman Empire) from 1588 was found in Pit 2, while the upper part of Pit 6 had been destroyed by a younger pit, which still held Ottoman era find material and siege debris. Two shards of the same liquid container with so-called cut-glazed decoration has come to light from Pits 2 and 3, which means that they had been probably filled up at the same time.

Pits 8-9 were located southwards from the church. The time of their creation and fill periods are both somewhat enigmatic. Both of their lower parts, especially that of Pit 8 contained a large amount of medieval find material, and a very mixed fill above it, which contained finds both from the Ottoman and later periods. Because of the many shards which matched from these layers, I have handled the pottery of the two pits together. A silver denarius of Ferdinand II (1619-1637) without the exact year came to light from Pit 9. It is certain that both pits have been disturbed by the building of the monument of General Hentzi in the $19^{\text {th }}$ century, but no find material could be surely connected to this period.

Pits 10-13 have been excavated on the south-western side of the square, on the area of the former Royal Stables, which were built in the $19^{\text {th }}$ century and demolished after World War II. Pits 10-12 were located in close vicinity to each other, on the eastern boundary of the excavation. Pit 11 had been cut in half by the stable walls; furthermore, two fill periods could be observed both in this feature and Pit 10, one from the end of the Ottoman era (10b; 11b) and one modern (10a; 11a). Despite of this, the lower, 'b' section of Pit 11 can be viewed as the most closed find complex after Pit 1 , as it had been walled in by stones and mortar. Pits $10 \mathrm{~b}$ and 12 could be dated terminus ante quem to 1684-86, as a section of the town wall built at this time was in superposition with them. No $18^{\text {th }}-19^{\text {th }}$ century finds were found in Pit 12 , so it was probably spared from further disturbances.

Pit 13 lay north-westwards from these features, between two Ottoman era houses, on their courtyard, so to say. Although its original purpose is unknown, it counts as especially large among its kind, with a diameter of 3-3.5 meters and depth of 14 meters. More than half of the evaluated finds came out of this object. 
Its fill was multi-layered as well, because it could not be compacted sufficiently and the ground sank on its top multiple times, probably until the middle of the $19^{\text {th }}$ century. The stable wall had also disturbed its southern edge, but this part was excavated separately, so its find material did not mix with that of the other parts. A glass bottle decorated in Anabaptist style, with the date 1671 painted on its shoulder came out of this object. ${ }^{4}$

\section{Methods}

The find complexes have been processed by traditional typo-chronology, as using this kind of evaluation may make the use of statistical means and scientific methods easier in the future.

The Buda find material is extremely diverse, so the related papers from Hungary, the neighbouring countries and other provinces of the former Ottoman Empire (especially in the Balkans and Anatolia) had to be studied and the typology mirrors the experiences from this survey.

The system is divided to three levels. The first and most global of these uses the common terms of 'kitchen ware', 'table ware and liquid containers', 'other ceramic ware', 'stoves and other building ceramics'. The next level is of the 'ware groups', which have been numbered continuously and independently from the chapter numbers. These contain vessels with various shared characteristics, but these attributes may vary. For example, all of the china is in one 'ware group', despite of representing various shapes, such as cups, bowls and plates. Meanwhile, in the case of 'kitchen ware', the base form (for example pot), the firing colour, the rim shapes and surface altering methods (for example glazes, slips, decorations, etc.) played the main role in their categorisation. For this reason, the general characteristics and research history of the ware group always precedes the evaluation of the find material.

The most detailed level of the system is of the 'ware types', marked with further numbers and in some cases, letters. Thanks to this and the independent numbering of 'ware groups', they all have a unique identification number, first digit of which provides information about the main pottery group the shard in question belongs to. All visible characteristics of the shards were taken into consideration at this stage of classification. The distribution of 'ware types' among the find complexes and their possible dating - based on pieces originating from suitable contexts in the Szent György tér pits and from other, published materials - has also been noted.

\section{Results}

Based on the aforementioned system, 28 'ware groups' and within them, 92 'ware types' could be identified, which have produced results on more than one level. (Fig. 2.)

\section{Pottery find horizons between the $16^{\text {th }}$ and $18^{\text {th }}$ centuries}

Firstly, find horizons typical for shorter phases during these 200 years could be defined. These five periods are the following:

- I. The Jagellonian Era (1490-1526) and the period preceding and following the conquest of Buda (1541)

- II. Early Ottoman Era: the middle of the $16^{\text {th }}$ century - the sieges of the Long War $(1598 ; 1602 ; 1603)$ and the following reconstruction works

4 Kolláth 2013. 
- III. Middle and Late Ottoman Era: from the beginning of the $17^{\text {th }}$ century till the sieges of the reconquering wars $(1684 ; 1686)$

- IV. Period of the reconquering wars: reconstruction works after the sieges, demolishing or renovating the Ottoman or Medieval buildings (1684; 1686 - beginning of the $18^{\text {th }}$ century)

- V. First half of the $18^{\text {th }}$ century: settlement of the new, mainly German speaking inhabitants

It has to be noted that although the pottery types have shown considerable changes during these periods, the exact given dates are just of informative nature. The changes of quotidian life usually do not follow historical events day by day, but rather morph gradually over years or decades.

\section{Connections of the city district located on the area of the modern Szent György tér}

The first question was of the local production in this area. The processed find complexes could mostly serve with indirect information. However, some types of lead-glazed pots and Ottoman type table wares have shown high quantity, very uniform qualities and parallels solely in the Castle District of Buda. These factors hint that they have been manufactured locally;

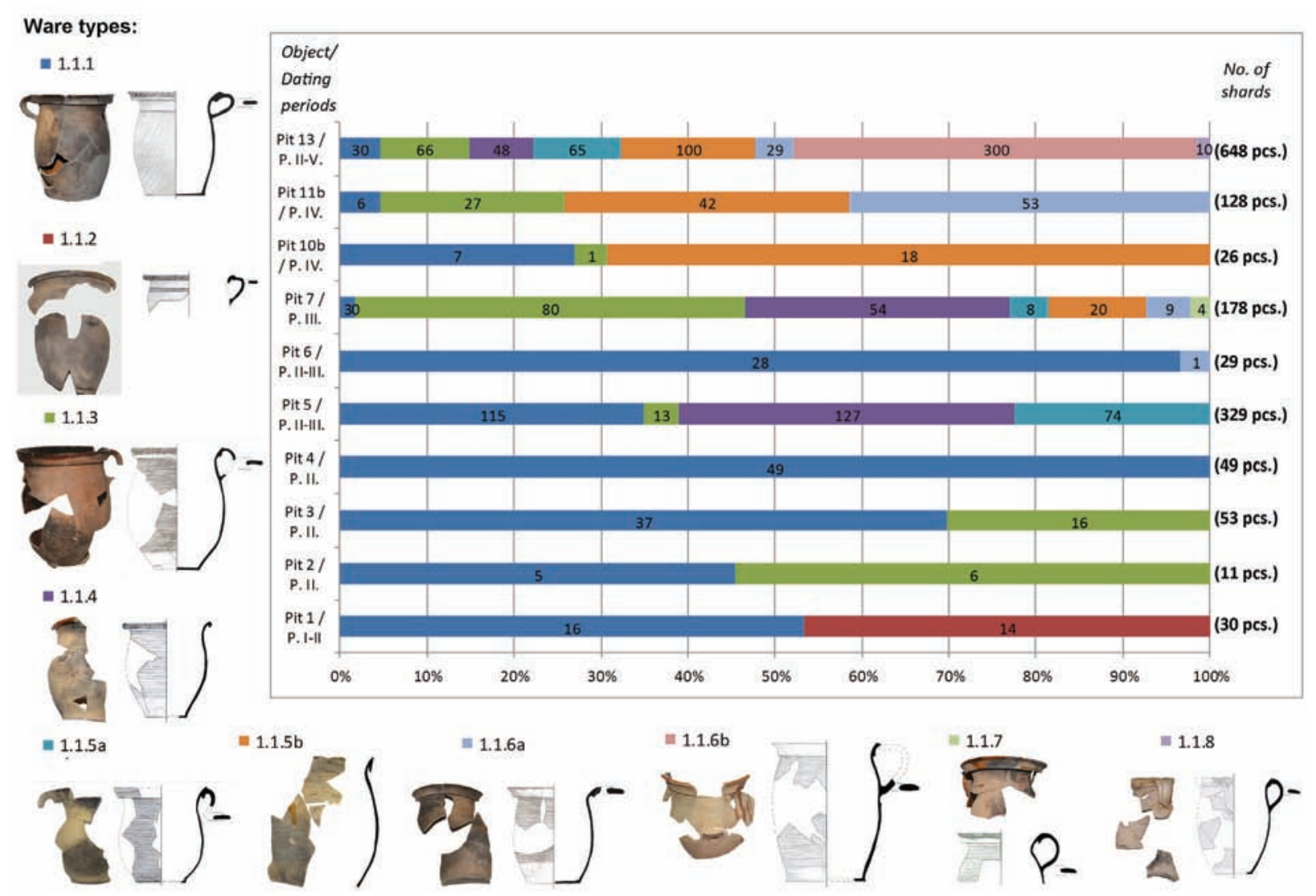

Fig. 2. An example for the results of using the typo-chronology presented in the dissertation. The chart shows the changes of 'ware type'-distribution of the wide-spread lead-glazed pots with collared or bent out rims in correlation with the dating of the evaluated features. The gradual transformation from the rather uniform (and likely imported) 'ware type 1.1.1' to a more varied and probably at least in part locally produced range of wares is palpable. Based on its $18^{\text {th }}$ century parallels, the dominance of the otherwise absent 'ware type 1.1.6b' in Pit 13 demonstrates that part of its filling process happened later than the closure of the other evaluated features (Drawings and photos by Â. Kollath). 
or at least in workshops serving exclusively this area. It could also be observed that these ware types did not show common characteristics with the pottery published from the Víziváros suburb of Buda. ${ }^{5}$

Regarding trade routes, the most vivid connections could be identified within the territory of the medieval Hungarian Kingdom, with the northern part of the Great Hungarian Plain and the southern region of the Felvidék (Highlands, today the southern part of Slovakia). They have also re-intensified in the $17^{\text {th }}$ century with the north-eastern part of the Transdanubian Region, west of the River Danube. Very few vessels show similarities to the types of the southern part of the Hungarian Great Plain, while even the Ottoman types differ from the material of the Southern Transdanubia.

It seems that the connections had not been completely severed in the $16^{\text {th }}$ century with Austria and other German speaking territories, but the wares typical of these regions have disappeared then for a time, probably because of the Long War. The western imports of the $17^{\text {th }}-18^{\text {th }}$ centuries differ from the earlier types.

Lastly, the most intensive ties within the Ottoman Empire existed with Belgrade. It is probable that among other goods pottery shipments had also arrived from here to the freshly conquered Buda, until the local production could be organised. The presence of china and faience and some other ware types partly hint at the trade directed here from the central provinces of the Empire (today Greece and Turkey), while a part of these vessels could have been personal belongings of the new inhabitants moving to Buda. The near exact parallels of some of the porcelain shards - found in $17^{\text {th }}$ century archaeological materials and collections from the Netherlands - point at the significant role of the Dutch East India Company in the transit trade between the Far East and the Ottoman Empire (Fig 3).

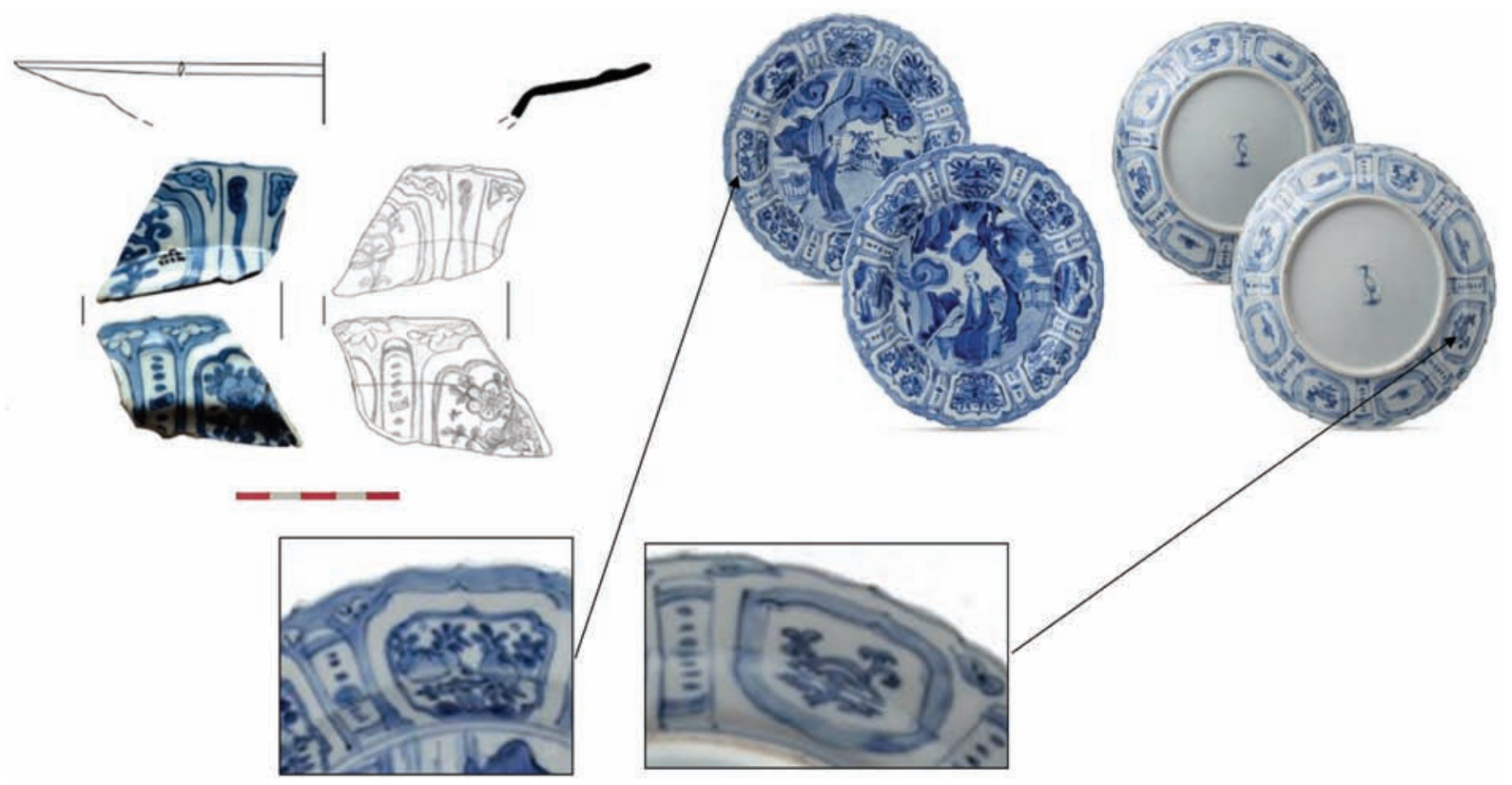

Fig. 3. Close parallels to one of the china shards from Pit 13 (Inv. No. 2012.287.70) found in the Jan Six (1618-1700) Collection in Amsterdam (Drawing and photos of the Budapest shard by Á. Kolláth; photos of the Amsterdam-plates after OsтKamp 2015).

5 For the Víziváros find material see GARÁdy 1944; ÉDER 2007; Éder 2013; ÉdER 2014; NÁDAI 2014; NÁDAI 2016. The pottery of the other historical suburbs of Buda or of Pest is much less studied. 


\section{New data on settlement history}

With the processing of their find material, the pits could be dated according to the aforementioned periods. Pit 1 could be placed in Periods I-II; Pits 2-4 to Period II; Pits 5-6 to Periods II-III; Pits 7 and 12 to Periods III; the lower 'b' sections of Pits 10 and 11 to Period IV. The find material of Pits 8-9 was mixed, their final filling could have happened in Period IV or rather V. The lowest part of the fill of Pit 13 contained mostly finds from Period II, its middle part showed the characteristics of Periods III-IV, while its top fill layer was mixed, partly with Period V or even later finds.

The evaluation of the pits has also served with information regarding the history of the site and its past inhabitants. The case of the church of Szent Zsigmond is especially interesting, as - contrary to earlier theories - it has been possibly used to secular purposes after the conquest, presumably as a dwelling. ${ }^{6}$ According to the periodization and finds of Pits $2-5$, which were excavated inside the building, it seems possible that the church had been damaged during the sieges of the Long War or because of some other catastrophe (conflagration, thunder strike, etc.), and required repairs and tidying. A change in function was also likely at this time, perhaps because of the ruined state of the church naves or following the Pasha's and his entourage's move to the neighbouring blocks. It is certain though, that no more pits had been dug inside the building, only Pit 5 remained in use for a while.

In summary, although more than a few unsolved problems remain, the processing of this larger find material gave opportunity to answer or elaborate many of the typological and chronological questions concerning the Early Modern Period pottery of Buda. Furthermore, creating the base models of the typical find horizons was also possible.

This work has also helped to obtain a better knowledge of the Ottoman Era history at a location with less than ideal stratigraphic properties, which shows the significance of the processing of pottery and other finds at such sites.

\section{References}

ÉDER, K. 2007: Török kori fajanszok a Víziváros területéről (Faience wares from the Turkish period in the area of the Víziváros). Budapest Régiségei 41, 239-247.

ÉDER, K. 2013: Törökkori díszkerámiák a Budapest-Víziváros területéről (Zierkeramiken aus der Türkenzeit aus Budapest-Víziváros(Wasserstadt). Budapest Régiségei 46, 187-195.

ÉDER, K. 2014: Hódoltságkori gödör a Víziváros területéről. Egy szemeskályha maradványai és kísérőleletei (A pit from the Ottoman Era in Budapest, Víziváros). Budapest Régiségei 47, 283-311.

FeKete L. 1944: Budapest a törökkorban. Budapest Története 3. Budapest.

FELD I. 1999: Beszámoló az egykori budai Szent Zsigmond templom és környéke feltárásáról. Budapest Régiségei 33, 35-50.

GARÁdy S. 1944: Agyagművesség. In: Fekete Lajos: Budapest a törökkorban. Budapest története III. Budapest, 382-402.

GERŐ, Gy. 1959: Hol állott a budai Kücsük dzsámi? (Ou était le Kutchuk djami de Buda?) Budapest Régiségei 19, 215-220.

Hegyi K. 2007: A török hódoltság várai és várkatonasága 1-3. Budapest. 
KÁrpáti, Z. 2003: A Szent Zsigmond-templom és környéke. Régészeti jelentés. (The St. Sigismund Church. Archaeological Report). Tanulmányok Budapest Múltjából 31, 205-240.

Kolláth, Á. 2013: An Enamel-Painted Glass Bottle from a „Turkish Pit” in Buda. Acta Archaeologica Academiae Scientiarum Hungaricae 64, 173-182.

KovÁcs, E. 2003: A budai ferences kolostor a török korban (The Franciscan Cloister in Buda Castle during the Turkish Period.). Tanulmányok Budapest Múltjából 31, 241-262.

Magyar, K. 2003: A budavári Szent György tér és környékének kiépülése. Történeti vázlat 1526-tól napjainkig. (The Formation of St. George Square and the Changing Face of It. 1526-2003.) Tanulmányok Budapest Múltjából 31, 43-126.

NÁDAI Zs. 2014: Kora újkori kerámia a budai Vízivárosból. Redukált égetésű folyadéktároló edények. In: Rácz T. Á. (szerk.): A múltnak kútja. Fiatal középkoros régészek V. konferenciájának tanulmánykötete. Szentendre, 35-49.

NÁDAI Zs. 2016: Kora újkori kerámia a Kacsa utca 15-17. lelöhelyról. MA thesis, ELTE BTK, manuscript. Budapest.

NyéKhelyi D. 2003: Középkori kútlelet a budavári Szent György téren. Monumenta Historica Budapestinensia 12. Budapest.

Ostкамp, S. 2015: Uit de Collectie Six: Reigermerk-Porselein. Vind Magazine 20, 101-103.

Simon K. 2017: Magyar várostörténeti atlasz 5. Buda. II. kötete (1686-1849) (Hungarian Atlas of Historic Towns No. 5. Buda. Part II.) Budapest.

Sudár B. 2014: Dzsámik és mecsetek a hódolt Magyarországon. Magyar Történelmi Emlékek. Adattárak. Budapest.

VÉGH A. 2003: Középkori városnegyed a Kiráyi palota előterében. A budavári Szent György tér és környezetének története a középkorban. Tanulmányok Budapest Múltjából 31, 7-42.

VÉGH A. 2006: Buda város középkori helyrajza 1. Monumenta Historica Budapestinensa 15. Budapest.

VÉGH A. 2008: Buda város középkori helyrajza 2. Monumenta Historica Budapestinensa 16. Budapest. 
